\section{JURNAL EKONOMI EFEKTIF}

ISSN : $2622-8882$, E-ISSN : 2622-9935

Jurnal Ekonomi Efektif, Vol. 3, No. 3, April 2021

@Prodi Manajemen Fakultas Ekonomi Universitas

Pamulang

\title{
PENGARUH MODAL KERJA BERSIH TERHADAP LABA SETELAH PAJAK PADA PT. MAYORA INDAH TBK PERIODE 2010-2019
}

\author{
Ria Rosalia Simangunsong \\ Universitas Pamulang, Tangerang Selatan, Banten, Indonesia \\ dosen02511@unpam.ac.id
}

Manuskrip: Feb-2021 Ditinjau: Feb-2021; Diterima: Feb-2021; Online: Apr-2021; Diterbitkan: Apr-2021

\begin{abstract}
ABSTRAK
Penelitian ini bertujuan untuk mengetahui pengaruh Modal Kerja Bersih terhadap Laba Setelah Pajak pada PT. Mayora Indah Tbk Periode 2010-2019. Metode yang digunakan adalah explanatory research. Teknik analisis menggunakan analisis statistik dengan pengujian regresi, korelasi, determinasi dan uji hipotesis. Hasil penelitian ini variabel Modal Kerja Bersih diperoleh nilai rata-rata sebesar 3,283\%. Variabel Laba Setelah Pajak diperoleh nilai rata-rata 905.40\%. Modal Kerja Bersih berpengaruh positif dan signifikan terhadap Laba Setelah Pajak dengan nilai persamaan regresi $\mathrm{Y}=147,131+320,600 \mathrm{X}$, dan nilai koefisien korelasi 0,809 atau memiliki tingkat hubungan yang sangat kuat dengan nilai determinasi $65,5 \%$. Uji hipotesis diperoleh signifikansi $0,000<0,05$.
\end{abstract}

Kata Kunci: Modal Kerja Bersih, Laba Setelah Pajak.

\section{ABSTRACT}

This study aims to see the effect of Net Working Capital on Profit After Tax at PT. Mayora Indah Tbk Period 2010-2019. The method used is explanatory research. The analysis technique uses statistical analysis with regression, regression, determination and hypothesis testing. The variable of the results of this research is Net Working Capital, the average value is $3.283 \%$. The profit after tax variable obtained an average value of $905.40 \%$. Net Working Capital has a positive and significant effect on Profit After Tax with the regression equation value $Y=147,131+320,600 X$, and the attribute value is 0.809 or has a very strong level of relationship with a determination value of $65.5 \%$. Hypothesis testing obtained a significance of $0.000<0.05$.

Keywords: Net Working Capital, Profit After Tax. 


\section{PENDAHULUAN}

\section{A. Latar Belakang Masalah}

Kebutuhan masyarakat yang tidak terbatas yang diikuti kecanggihan teknologi, sehingga perkembangan dunia usaha semakin meningkat untuk memenuhi kebutuhan masyarakat dan timbul persaingan kompetitif. Perusahaan yang sangat kuat akan bertahan sebaliknya perusahaan yang tidak mampu bersaing kemungkinan akan mengalami kebangkrutan. Untuk dapat terus menerus mempertahankan kesinambungan kegiatan operasinya pada saat ini, sebuah perusahaan dituntut untuk selalu inovatif dan mampu menyesuaikan diri dengan perubahan-perubahan yang terjadi dalam lingkungannya. Perubahan-perubahan tersebut dapat berupa perubahan ekonomi nasional, peraturan pemerintah, kondisi konsumen, maupun kemampuan pesaing. Beberapa yang juga perlu diperhatikan oleh perusahaan untuk dapat menjamin kesinambungan hidupnya adalah mampu meningkatkan produktivitas, daya saing, keuntungan usaha, dan kualitas perusahaan.

Dalam menjalankan kegiatan operasional setiap perusahaan membutuhkan modal kerja. Penetapan besarnya modal kerja yang dibutuhkan perusahaan berbeda-beda, salah satunya tergantung pada jenis perusahaan dan besar kecilnya perusahaan itu sendiri. Penentuan jumlah modal kerja sangatlah penting bagi perusahaan, karena jika kekurangan modal kerja maka perusahaan akan mengalami likuiditas yaitu tidak bisa membayar kewajiban jangka pendek tepat pada waktunya, dan akan mengalami kesulitan dalam membeli bahan baku, membayar gaji karyawan, serta biaya-biaya lainnya yang akan mengakibatkan tidak maksimumnya kegiatan operasional perusahaan.

Modal yang dikeluarkan oleh perusahaan itu dapat diharapkan dapat masuk kembali dalam jangka pendek melalui hasil penjualan produk maupun untuk jangka panjang melalui investasinya. Uang masuk yang berasal dari penjualan produk tersebut akan segera dikeluarkan untuk membiayai kegiatan operasionalnya. Dengan demikian maka dana tersebut akan terus menerus berputar setiap periodenya selama perusahaan itu berdiri. Untuk mengetahui berapa jumlah modal kerja yang dibutuhkan oleh perusahaan, manajer melakukan analisis terhadap modal kerjanya yang didasarkan kepada informasi atau laporan keuangan perusahaan kemudian dikaitkan dengan laba yang diperoleh perusahaan.

Sementara itu, jika perusahaan menetapkan modal kerja yang berlebihan menyebabkan perusahaan overlikuid sehingga menimbulkan dana yang menganggur yang akan mengakibatkan kerugian bagi perusahaan dan membuang kesempatan memperoleh laba. Oleh karena itu untuk mengetahui berapa jumlah modal kerja yang dibutuhkan oleh perusahaan, kemudian dikaitkan dengan laba yang diperoleh perusahaan. Dalam kaitannya dengan Profitabilitas, untuk menilai keberhasilan perusahaan didalam kemampuannya untuk meraih laba pada tahun berjalan maupun pada tahun sebelumnya, perusahaan menghendaki agar seluruh dana dioperasikan, sehingga tidak ada dana yang menganggur yang akan merugikan perusahaan karena adanya biaya dana. Maka dari itu para investor biasanya sangat memperhatikan kemampuan perusahaan memperoleh laba atas penggunaan modalnya.

PT. Mayora Indah Tbk merupakan salah satu perusahaan di Indonesia yang bergerak dalam bidang industri, perdagangan serta agen/perwakilan. Saat ini PT. Mayora Indah Tbk memproduksi biscuit, wafer, permen, coklat, kopi, dan makanan kesehatan serta menjual produknya di pasar local dan luar negri.

Dalam menjalankan aktivitasnya sehari-hari PT. Mayora Indah Tbk dituntut untuk mempunyai modal kerja bersih yang cukup. Modal kerja bersih pada PT. Mayora Indah Tbk digunakan untuk membiayai kegiatan operasi perusahaan seperti membayar gaji 
karyawan, pembelian bahan mentah, dan lain-lain. Tujuan akhir yang ingin dicapai suatu perusahaan yang terpenting adalah memperoleh laba bersih yang maksimal. Oleh karena itu manajemen perusahaan dalam praktiknya dituntut harus mampu untuk memenuhi target yang telah ditetapkan. Artinya besarnya keuntungan haruslah dicapai sesuai dengan yang diharapkan. Pada tahun-tahun berikutnya perusahaan melakukan ekspansi cepat menjadi sebuah perusahaan yang berbasis ASEAN. Salah satu usahanya mendirikan fasilitas produksi dan beberapa kantor pemasaran yang terletak dibeberapa Negara di Asia Tenggara.

Pada umumnya usaha atau aktivitas perusahaan sebagai pelaku ekonomi berorientasikan laba yang akan digunakan bagi kelangsungan hidup perusahaan dimasa yang akan datang. Perusahaan harus dapat menggunakan modal kerja yang tersedia secara baik agar penerimaan yang diperoleh perusahaan dapat meningkat dari tahun ke tahun serta untuk menghindari kesulitan keuangan yang sangat berpengaruh pada perkembangan perusahaan.

Berdasarkan latar belakang di atas, maka penulis tertarik untuk melakukan penelitian dengan judul: "Pengaruh Modal Kerja Bersih Terhadap Laba Setelah Pajak Pada PT. Mayora Indah Tbk".

\section{B. Rumusan Masalah}

1. Bagaimana Modal Kerja Bersih pada pada PT. Mayora Indah Tbk ?.

2. Bagaimana Laba Setelah Pajak pada PT. Mayora Indah Tbk?.

3. Adakah pengaruh antara Modal Kerja Bersih terhadap Laba Setelah Pajak pada PT. Mayora Indah Tbk?

\section{Tujuan Penelitian}

1. Untuk mengetahui kondisi Modal Kerja Bersih pada PT. Mayora Indah Tbk.

2. Untuk mengetahui kondisi Laba Setelah Pajak pada PT. Mayora Indah Tbk.

3. Untuk mengetahui pengaruh antara Modal Kerja Bersih terhadap Laba Setelah Pajak pada PT. Mayora Indah Tbk.

\section{METODE PENELITIAN}

\section{Populasi} tahun.

Populasi dalam penelitian ini laporan keuangan PT. Mayora Indah Tbk selama 10

\section{Sampel}

Teknik pengambilan sampling dalam penelitian ini adalah samplel jenuh, dimana semua anggota populasi dijadikan sebagai sampel. Dengan demikian sampel dalam penelitian ini laporan keuangan PT. Mayora Indah Tbk selama 10 tahun.

\section{Jenis Penelitian}

Jenis penelitian yang dipakai adalah asosiatif, dimana tujuannya adalah untuk mengetahui mencari keterhubungan antara variabel independen terhadap variabel dependennya.

\section{Metode Analisis Data}

Dalam menganalisis data digunakan uji validitas, uji reliabilitas, analisis regresi linier sederhana, koefisien korelasi, koefisien determinasi dan uji hipotesis.

\section{HASIL PENELITIAN DAN PEMBAHASAN}

\section{Analisis Deskriptif}

Pada pengujian ini digunakan untuk mengetahui skor minimum dan maksimum 
skor tertinggi, ratting score dan standar deviasi dari masing-masing variabel. Adapun hasilnya sebagai berikut:

Tabel 1. Hasil Analisis Descriptive Statistics

Descriptive Statistics

\begin{tabular}{|lr|r|r|r|r} 
& N & Minimum & Maximum & \multicolumn{1}{c}{ Mean } & Std. Deviation \\
\hline Modal Kerja Bersih (X) & 10 & 1.55 & 4.86 & 3.2830 & 1.12744 \\
\hline Laba Setelah Pajak (Y) & 10 & 382.00 & 1455.00 & 905.4000 & 446.67468 \\
\hline Valid N (listwise) & 10 & & & & \\
\hline
\end{tabular}

Modal Kerja Bersih diperoleh nilai minimum sebesar 1,55 dan nilai maximum 4,86 dengan rata-rata sebesar 3,283 dengan standar deviasi 1,127. Laba Setelah Pajak diperoleh nilai minimum sebesar 3812 dan nilai maximum 1.455 dengan rata-rata sebesar 905.40 dengan standar deviasi 446,67.

\section{Analisis Verifikatif.}

Pada analisis ini dimaksudkan untuk mengetahui pengaruh variabel independen terhadap variabel dependen. Adapun hasil pengujian sebagai berikut:

\section{a. Analisis Regresi Linier Sederhana}

Uji regresi ini dimaksudkan untuk mengetahui perubahan variabel dependen jika variabel independen mengalami perubahan. Adapun hasil pengujiannya sebagai berikut:

Tabel 2. Hasil Pengujian Regresi Linier Sederhana

\section{Coefficients $^{\mathrm{a}}$}

Unstandardized

Coefficients

\begin{tabular}{lr|r|r|r|r} 
Model & \multicolumn{1}{c}{ B } & Std. Error & Beta & \multicolumn{1}{c}{ t } & \multicolumn{1}{c}{ Sig. } \\
\hline 1 (Constant) & 147.131 & 284.143 & & .518 & .619 \\
\hline Modal Kerja Bersih $(\mathrm{X})$ & 320.600 & 82.293 & .809 & 3.896 & .005 \\
\hline
\end{tabular}
berikut:

regresi $\mathrm{Y}=147,131+320,600 \mathrm{X}$. Dari persamaan tersebut dijelaskan sebagai

1) Konstanta sebesar 147,131 diartikan jika Modal Kerja Bersih tidak ada, maka telah terdapat nilai Laba Setelah Pajak sebesar 147,131 point.

2) Koefisien regresi Modal Kerja Bersih sebesar 320,600, angka ini positif artinya setiap ada peningkatan Modal Kerja Bersih sebesar 320,600 point maka Laba Setelah Pajak juga akan mengalami peningkatan sebesar 320,600 point.

\section{b. Analisis Koefisien Korelasi}

Analisis koefisien korelasi dimaksudkan untuk mengetahui tingkt kesangat kuatan hubungan dari variabel independen terhadap variabel dependen baik secara parsial maupun simultan. Adapun hasil pengujian sebagai berikut:

Tabel 3. Hasil Pengujian Koefisien Korelasi Modal Kerja Bersih Terhadap Laba

Setelah Pajak.

\section{Correlations $^{\mathbf{b}}$}

\begin{tabular}{llr|r} 
& & $\begin{array}{c}\text { Modal Kerja } \\
\text { Bersih (X1) }\end{array}$ & \multicolumn{1}{c}{$\begin{array}{c}\text { Laba Setelah } \\
\text { Pajak (Y) }\end{array}$} \\
\hline Modal Kerja Bersih (X) & Pearson Correlation & 1 & $.809^{* *}$ \\
\cline { 2 - 4 } & Sig. (2-tailed) & & .005 \\
\hline Laba Setelah Pajak (Y) & Pearson Correlation & $.809^{* *}$ & 1 \\
\cline { 2 - 4 } & Sig. (2-tailed) & .005 & \\
\hline
\end{tabular}


Berdasarkan hasil pengujian diperoleh nilai korelasi sebesar 0,809 artinya Modal Kerja Bersih memiliki hubungan yang sangat kuat terhadap Laba Setelah Pajak.

\section{c. Analisis Koefisien Determinasi}

Analisis koefisien determinasi dimaksudkan untuk mengetahui besarnya persentase pengaruh dari variabel independen terhadap variabel dependen. Adapun hasil pengujian sebagai berikut:

Tabel 4. Hasil Pengujian Koefisien Determinasi Modal Kerja Bersih Terhadap Laba

Setelah Pajak.

Model Summary

\begin{tabular}{lr|r|r|r} 
Model & R & R Square & Adjusted R Square & Std. Error of the Estimate \\
\hline 1 & $.809^{\mathrm{a}}$ & .655 & .612 & 278.34119 \\
\hline
\end{tabular}

Berdasarkan hasil pengujian diperoleh nilai determinasi sebesar 0,655 artinya Modal Kerja Bersih memiliki kontribusi pengaruh sebesar $65,5 \%$ terhadap Laba Setelah Pajak.

\section{d. Uji Hipotesis}

Pengujian hipotesis dengan uji t digunakan untuk mengetahui hipotesis mana yang diterima. Rumusan hipotesis: Terdapat pengaruh yang signifikan antara Modal Kerja Bersih terhadap Laba Setelah Pajak.

Tabel 5. Hasil Uji Hipotesis Modal Kerja Bersih Terhadap Laba Setelah Pajak.

\section{Coefficients $^{\mathrm{a}}$}

Unstandardized Standardized

Coefficients Coefficients

\begin{tabular}{|c|c|c|c|c|c|}
\hline Model & B & Std. Error & Beta & $\mathrm{t}$ & Sig. \\
\hline 1 (Constant) & 147.131 & 284.143 & & -.518 & .619 \\
\hline Modal Kerja Bersih (X) & 320.600 & 82.293 & .809 & 3.896 & .005 \\
\hline
\end{tabular}

Berdasarkan hasil pengujian pada tabel di atas, diperoleh nilai t hitung $>\mathrm{t}$ tabel atau $(3,896>2,306)$, dengan demikian hipotesis yang diajukan bahwa terdapat pengaruh yang signifikan atara Modal Kerja Bersih terhadap Laba Setelah Pajak diterima.

\section{PEMBAHASAN HASIL PENELITIAN}

\section{Kondisi Jawaban Responden Variabel Modal Kerja Bersih}

Berdasarkan data empiris dan analisis data, variabel Modal Kerja Bersih diperoleh nilai rata-rata per tahun sebesar 3,283\%.

\section{Kondisi Jawaban Responden Variabel Laba Setelah Pajak}

Berdasarkan data empiris dan analisis data, variabel Laba Setelah Pajak diperoleh nilai rata-rata per tahun sebesar $905.40 \%$.

\section{Pengaruh Modal Kerja Bersih Terhadap Laba Setelah Pajak}

Modal Kerja Bersih berpengaruh signifikan terhadap Laba Setelah Pajak dengan persamaan regresi $\mathrm{Y}=147,131+320,600 \mathrm{X}$, nilai korelasi sebesar 0,809 atau memiliki hubungan yang sangat kuat dengan kontribusi pengaruh sebesar $65,5 \%$. Pengujian hipotesis diperoleh nilai t hitung $>\mathrm{t}$ tabel atau $(3,896>2,306)$. Dengan demikian hipotesis yang diajukan bahwa terdapat berpengaruh signifikan antara Modal Kerja Bersih terhadap Laba Setelah Pajak diterima. 


\section{PENUTUP}

\section{Kesimpulan}

a. Variabel Modal Kerja Bersih diperoleh ratting score sebesar 3,283 berada di rentang skala 3,40 - 4,19 dengan kriteria baik atau setuju.

b. Variabel Laba Setelah Pajak diperoleh ratting score sebesar 905.40 berada di rentang skala 3,40-4,19 dengan kriteria baik atau setuju.

c. Modal Kerja Bersih berpengaruh signifikan terhadap Laba Setelah Pajak dengan persamaan regresi $\mathrm{Y}=147,131+320,600 \mathrm{X}$, nilai korelasi sebesar 0,809 atau sangat kuat dan kontribusi pengaruh sebesar $65,5 \%$ sedangkan sisanya sebesar $57,9 \%$ dipengaruhi faktor lain. Uji hipotesis diperoleh nilai $t$ hitung $>t$ tabel atau $(3,896>$ 2,306).

\section{Saran}

a. Perusahaan sebaiknya selalu berusaha meningkatkan periode perputaran modal kerja bersih. Usaha yang dapat dilakukan yaitu dengan cara memanfaatkan modal kerja bersih secara efesien, agar perputaran modal kerja bersih naik setiap tahunnya.

b. Perusahaan harus menghemat pengeluaran serta dapat meningkatkan persediaan serta penjualan pada tiap tahunnya, sehingga laba yang diperoleh perusahaan setiap tahunnya terus mengalami peningkatan.

c. Penelitian selanjutnya, sebaiknya meneliti variabel indenpenden lain yang dapat mempengaruhi laba setelah pajak dan menambah sampel penelitian yang lebih luas sehingga dapat lebih memperlihatkan apa saja yang dapat mempengaruhi laba setelah pajak tersebut.

\section{DAFTAR PUSTAKA}

Agus Harjito \& Martono, (2010) "Manajemen Keuangan" Yogyakarta: Penerbit Ekonisia. Agus Sartono. (2010). "Manajemen Keuangan Toeri dan Aplikasi", Edisi keempat, Yogyakarta: Penerbit BPFE.

Algifari. (2015). “Analisis Regresi untuk Bisnis dan Ekonomi”. Yogyakarta: BPFE.

Arikunto, Suharsimi (2014). "Prosedur Penelitian Suatu Pendekatan Praktek". Jakarta: Rineka Cipta.

Bambang Riyanto, (2011). "Dasar-dasar Pembelanjaan Perusahaan". Edisi ke empat, BPFE Yogyakarta.

Fahmi, Irham (2012), "Pengantar Manajemen Keuangan" Cetakan pertama. Bandung: Penerbit Alfabeta.

Haque, M. G., Nurjaya, N.,Affandi, A., Erlangga, H., \& Sunarsi, D. (2021). Micro Financial Sharia Non-bank Strategic Analysis: a Study at BMT Beringharjo, Yogyakarta. Budapest International Research and Critics Institute (BIRCI-Journal): Humanities and Social Sciences, 4(2), 1677-1686.

Imam Ghozali (2017). "Aplikasi Analisis Multivariate Dengan Program SPSS”. Edisi Kelima. Semarang: Badan Penerbit Undip.

Istijanto (2014) "Riset Sumber Daya Manusia". Jakarta: PT. Gramedia Pustaka

Jasmani, J. (2018). Pengaruh Kinerja Keuangan Terhadap Harga Saham (Analisis Pada Perusahaan Property dan Real Estate Yang Go Public di Bursa Efek Indonesia. Jurnal Akuntansi Indonesia, 12(2).

Jasmani, J. (2019). The Effect of Liquidity and Working Capital Turnover on Profitability at PT. Sumber Cipta Multiniaga, South Jakarta. PINISI Discretion Review, 3(1), 2938. 
Kasmir (2010), “Analisis Laporan keuangan”, penerbit raja grafindo persada, Jakarta

Kasmir, (2010). "Pengantar Manajemen Keuangan", Edisi Pertama, Cetakan kedua, Jakarta: Penerbit Prenada Media.

Kasmir. (2012) "Pengantar Manajemen Keuangan", Edisi Pertama, Cetakan kedua, Jakarta: Prenada Media.

Martono dan Agus Harjito, (2011). "Manajemen Keuangan", Jakarta: Penerbit Ekonisia..

Munawir (2010), “Analisis Laporan Keuangan”, Edisi Ke Empat, Penerbit Liberty, Yogyakarta.

Noryani, Y. B. G., Sari, W. I., Rosini, I., Munadjat, B., Sunarsi, D., \& Mahnun Mas' adi, G. (2020). Did ISO 45001, ISO 22000, ISO 14001 and ISO 9001 Influence Financial Performance? Evidence from Indonesian Industries. PalArch's Journal of Archaeology of Egypt/Egyptology, 17(7), 6930-6950.

Pujiati, H., Sunarsi, D., Affandi, A., \& Anggraeni, N. (2021). Effect of ISO 9001: 2015 Quality Management Implementation in Education on School Performance. Journal of Contemporary Issues in Business and Government, 27(1), 1848-1855.

Santoso, Singgih (2015). "Menguasai Statistik Multivariat". Jakarta: PT Elex Media Komputindo.

Sartono, "Manajemen Keuangan Aplikasi Dan Teori”, Edisi Keempat, BPFE, Yogyakarta, 2008.

Sawir, (2003). “Analisis Kinerja Keuangan dan Perencanaan Keuangan Perusahaan”, Cetakan ketiga, Jakarta: Penerbit PT. Gramedia Pustaka Utama.

Sugiyarso, G. dan F. Winarni, "Manajemen Keuangan (Pemahaman Laporan Keuangan, Pengelolaan Aktiva, Kewajiban dan Modal serta Pengukuran

Sugiyono (2017), "Metode Penelitian Administrasi : dilengkapi dengan Metode R \& D". Bandung: Alfabeta.

Suhartono, A., Jati, W., \& Sunarsi, D. (2019). Pengaruh Earning Per Share Dan Return On Asset Terhadap Harga Saham Pada PT. Bank Negara Indonesia Tbk Periode 20092018. Jurnal Manajemen, Bisnis dan Organisasi (JUMBO), 3(3), 182-194. 